\title{
Monitor Kualitas Udara Berbasis Web Menggunakan Raspberry Pi dan Modul Wemos D1
}

\author{
${ }^{1}$ Frenki Tahir, ${ }^{2}$ Wrastawa Ridwan, ${ }^{3}$ Iskandar Z. Nasibu \\ 1,2,3 Jurusan Teknik Elektro, Fakultas Teknik, Universitas Negeri Gorontalo \\ Jl. Jendral Sudirman No.6 Kota Gorontalo 96128 Indonesia \\ e-mail: frenkitahir21@gmail.com
}

\begin{abstract}
Abstrak
Polusi udara adalah zat fisik, kimia, maupun biologi yang dapat membahayakan kesehatan dan dapat menimbulkan penyakit pada mahkluk hidup. Oleh karena itu, pengetahuan tentang kualitas udara menjadi sangatlah penting. Penelitian ini bertujuan untuk merancang dan membangun prototipe sistem monitor kualitas udara berbasis web dengan menerapkan teknologi Jaringan Sensor Nirkabel (JSN). Metode komunikasi yang digunakan antara client dan server adalah komunikasi protokol Webscoket.io, dengan tujuan untuk mengurangi latency pada jaringan. Perancangan sistem dibagi dalam dua bagian yaitu perancang perangkat keras dan perangkat lunak pada server, mikrokontroler dan user client. Hasil yang diperoleh adalah telah dapat dibuat prototipe sistem monitor kualitas udara yang menggunakan Raspberry Pi sebagai server dan modul Wemos D1 sebagai modul wifi. Sistem telah bekerja dengan baik sesuai dengan yang diinginkan. Pada uji coba yang dilakukan pada lokasi pertama (dalam ruangan, tanpa AC) diperoleh pembacaan suhu $29^{\circ} \mathrm{C}$, kelembaban $32 \%$, kadar gas $\mathrm{CO}_{2}$ dan $\mathrm{CO}$ bertutur-turut 2,44 ppm dan 2,15 ppm. Lokasi kedua (luar ruangan, dekat jalan) diperoleh data $32^{\circ} \mathrm{C}, 67 \%, 193,62$ ppm, 4,86 ppm, sedangkan di lokasi ketiga (dalam ruangan, ber-AC) diperoleh data $27^{\circ} \mathrm{C}, 63 \%$, $7,5 \mathrm{ppm}$ dan $0,87 \mathrm{ppm}$.
\end{abstract}

Kata kunci: kualitas udara, jaringan sensor nirkabel, Raspberry Pi, modul wifi Wemos D1

\begin{abstract}
Air pollutant is a physical, chemical, and biological substance that can endanger the health and can cause disease in living beings. Therefore, knowledge about air quality is very important. This research aims to implement a wireless sensor network for monitoring air quality, from three different location points which are presented in the form of a website. The communication used between the client and server is the Webscoket.io communication protocol, to reduce network latency. In addition, the communication protocol works in real-time because not only the client can send a request to the server, but also can receive a response without having to send a request first. The research method used is the experimental method, which is divided into two stages namely hardware design stage and server software, microcontroller and user client design stage. The results obtained are prototyping tools used to implement wireless sensor networks for monitoring air quality using Raspberry Pi as a server and Arduino ESP-8266 as a microcontroller module. The tools have performed well as intended. In the trial, a reading of gas (CO2 and CO) sensors, temperature and humidity at the location being tested were successfully displayed on the website.
\end{abstract}

Keywords: air quality, wireless sensor network, Raspberry Pi, wifi module Wemos D1

Diterima: Maret 2020

Disetujui: Juni 2020

Dipublikasi: Juni 2020

(C2020 Frenki Tahir, Wrastawa Ridwan, Iskandar Z. Nasibu Under the license CC BY-SA 4.0

\section{Pendahuluan}

Berkembangnya teknologi komunikasi tidak lepas dari kebutuhan umat manusia untuk menyelesaikan suatu masalah. Salah satu teknologi yang berkembang saat ini adalah teknologi Jaringan Sensor Nirkabel (JSN) atau bisa juga disebut dengan internet 
of things (loT). Teknologi JSN merupakan salah satu teknologi komunikasi nirkabel yang terdiri dari beberapa alat sensor yang saling bekerja sama untuk memonitor fisik dan kondisi lingkungan seperti suhu, air, getaran atau gempa, polusi udara dan lain-lain ditempat yang berbeda. Penelitian dalam pemanfaatan JSN telah dilakukan oleh berbagai peneliti (Af'idah dkk (2014), Rahman (2016), Yuliza (2016), Widodo dkk (2017), Ridwan dkk (2018), Usman dkk (2019), dan Ridwan dkk (2020)).

Polusi udara merupakan hadirnya suatu zat fisik, kimia, maupun biologi di udara yang dapat membahayakan kesehatan, mengganggu estetika dan kenyamanan, atau merusak properti. Polusi udara ini semakin hari menampakkan kondisi yang sangat memprihatinkan. Menurut UU No. 23 Tahun 1997 tentang pengelolaan lingkungan hidup, pencemaran lingkungan hidup menurut pasal (1) adalah masuknya atau dimasukannya makhluk hidup, zat, energi atau berubahnya tatanan lingkungan oleh kegiatan atau aktifitas manusia atau proses alam sehingga kualitas lingkungan turun sampai tingkat tertentu yang menyebabkan lingkungan menjadi kurang atau tidak berfungsi lagi sesuai dengan peruntukannya (UU RI No. 23, 1997). Pencemaran lingkungan, dalam hal ini polusi udara, dapat menyebabkan berbagai gangguan kesehatan. Oleh karena itu, pengetahuan tentang kualitas udara secara real time menjadi sangat penting untuk menghindari dampak negatif polusi udara bagi kesehatan.

Beberapa penelitian telah dilakukan dalam memanfaatkan teknologi JSN. Pada penelitian yang dilakukan oleh Susana dkk (2016), JSN digunakan untuk mendeteksi kebakaran berupa api dan asap. Hasil pendeteksian kemudian dikirimkan melalui SMS (Short Message Service) sebagai notifikasi ke dua user yaitu ke pemadam kebakaran dan tim investigasi kebakaran. Monitor suhu dan kelembaban menggunakan modul Xbee dengan data pengukuran ditampilkan dalam bentuk grafik menggunakan bahasa javascript dan PHP. Sensor yang digunakan yaitu Sensor NTC, LM35DZ yang digunakan sebagai sensor suhu dan HS1101 sebagai sensor kelembaban (Ardiyanto \& Sumiharto, 2012). Penelitan yang dilakukan oleh Rachman membahas bagaimana membangun suatu sistem pemantau dan kendali ruang yang terpusat dengan menggunakan jaringan nirkabel ZigBee pada gelombang 2,4 GHz, terdiri dari beberapa perangkat diantaranya end device sebagai titik pemasangan, router sebagai jembatan penghubung antara end device dengan coordinator serta pengujian kinerja dari ZigBee itu sendiri. Selain itu, sistem pemantauan dan kendali ditampilkan dalam bentuk HMI (Human Machine Interface) sehingga mudah digunakan oleh operator dalam pengoperasiannya (Rachman, 2017). Pemanfaatan sensor gas untuk mengetahui kadar gas yang dihasilkan dalam reaktor gas dilakukan dengan memanfaatkan sensor MQ-2 (Ilham dkk, 2018). 
Pada penelitian ini diterapkan teknologi JSN, untuk monitor kualitas udara berbasis web di tiga lokasi yang berbeda. Perbedaan dengan penelitian-penelitian sebelumnya, pada penelitian ini ada 4 parameter kualitas udara yang akan diukur, yaitu kadar gas karbonmonoksida $(\mathrm{CO})$, kadar gas karbondioksida $\left(\mathrm{CO}_{2}\right)$, suhu dan kelembaban udara. Selain itu, data pengukuran ke-empat parameter ini secara real time ditampilkan pada aplikasi berbasis web. Data hasil pemantauan node-node sensor di tiga lokasi tersebut akan ditransmisikan ke coordinator secara wireless, dan kemudian data tersebut diolah oleh server menggunakan Raspberry Pi (Richardson \& Wallace, 2012, dan Pi, 2016). Raspberry Pi dijadikan server, karena alasan portabilitas yaitu Raspberry berukuran kecil dan hanya konsumsi daya sedikit. Dengan adanya sistem berbasis web monitor kualitas udara ini diharapkan kualitas udara di suatu tempat dapat lebih cepat diketahui sehingga dampak negatif adanya polusi udara dapat segera dihindari.

\section{Metode}

Metode yang digunakan pada penelitian ini adalah prototipe. Metode ini dipilih karena memungkinkan adanya pengembangan sistem ini. Perancangan sistem dibagi dalam dua bagian, yaitu perancangan perangkat keras (hardware) dan perangkat lunak (software).

\section{Perancangan Perangkat Keras}

Gambar 1 menunjukkan hubungan antara server, user dan node client, sedangkan diagram blok perangkat keras sistem dapat dilihat pada Gambar 2.

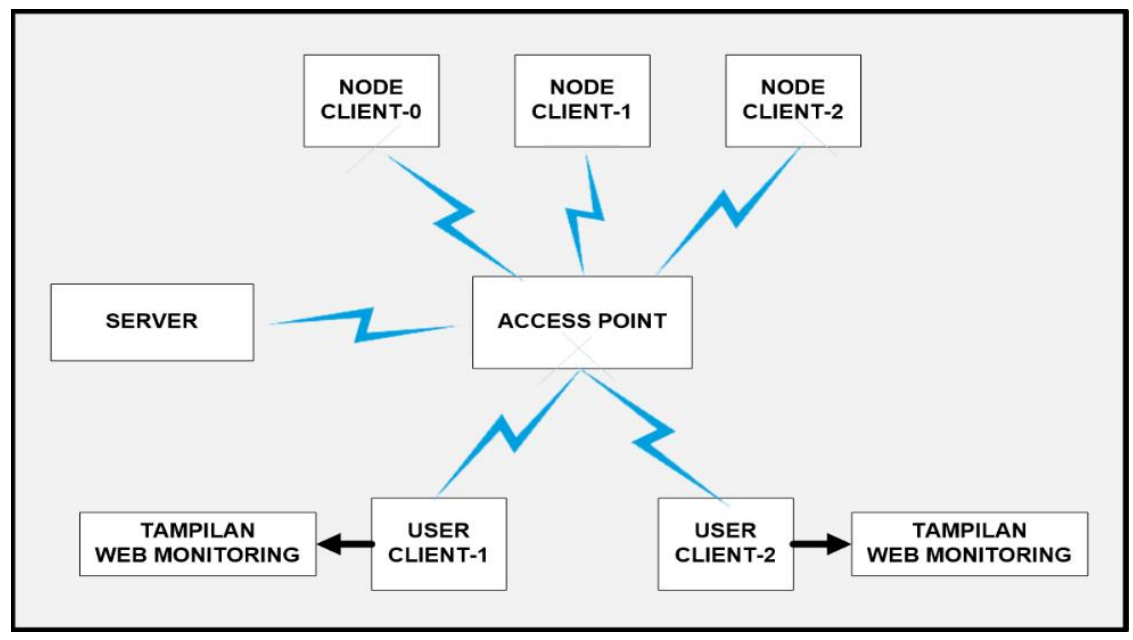

Gambar 1. Hubungan antara server, user dan node client

Gambar 1 memperlihatkan Raspberry Pi dijadkan sebagai server (pengolah/ pengirim data sensor) yang terkoneksi dengan Access Point dan node client juga terkoneksi dengan Access Point untuk mengirim data sensor ke server dan server menyimpan data tersebut. Jika ada perubahan data pada node client maka node client 
mengirim perubahan data tersebut ke server kemudian diteruskan data tersebut ke user yang terkoneksi dengan Access Point. Komunikasi yang digunakan antara server dan user menggunakan komunikasi WebSocket.io (Panser \& Yahya, 2018). Jika diantara server dan user sudah terkoneksi maka server dapat mengirim data ke user tanpa user harus mengirim request terlebih dahulu ke server. Data yang diperoleh oleh user secara real time dan ditampilkan dalam situs web.

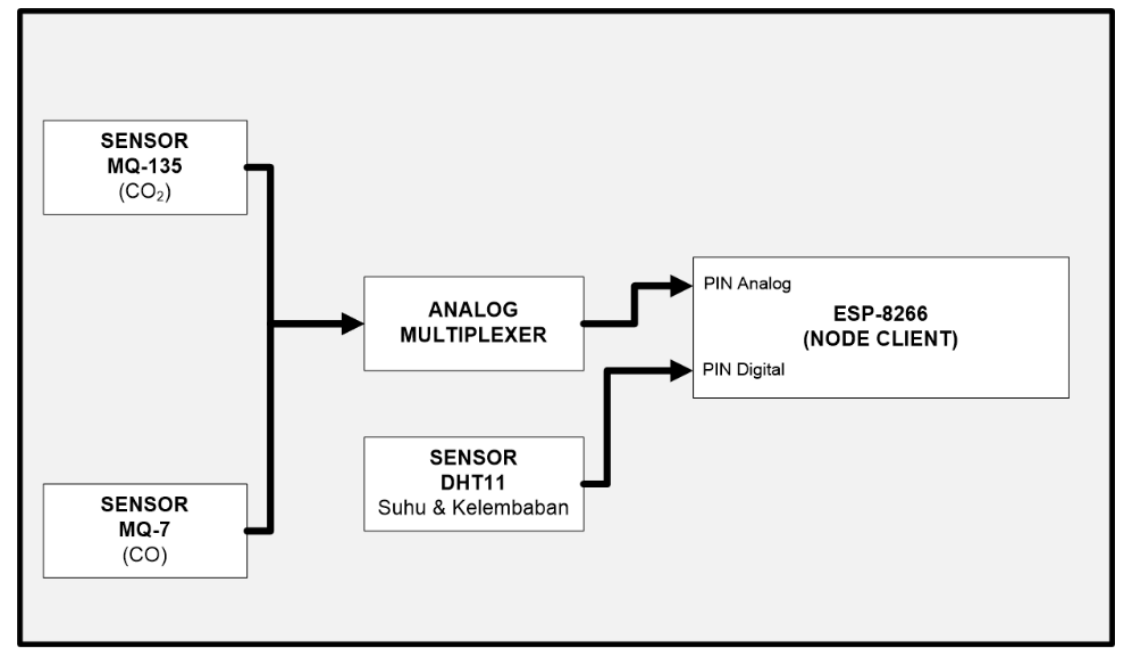

Gambar 2. Diagram blok sistem

Pada Gambar 2 Sensor MQ-135 dan Sensor MQ-7 terhubung pada analog multiplexer dan dari analog multiplexer terhubung pada Pin Analog ESP-8266 (ESP8266 Datasheet, 2015). Analog multiplexer sebagai penghubung antara sensor MQ-135 dan MQ-7 karena pin input analog pada ESP-8266 hanya 1 pin I/O analog, sedangkan yang dibutuhkan 2 pin I/O analog maka digunakan IC CD4052B sebagai analog multiplexer. Sensor DHT11 langsung terhubung dengan Pin DigitalESP-8266. Beberapa bagian dari Gambar 2 dijelaskan sebagai berikut.

\section{Sensor MQ-135}

MQ-135 Air Quality Sensor adalah sensor yang memonitor kualitas udara untuk mendeteksi gas amonia (NH3), natrium-(di) oksida (NOx), alkohol/ethanol $(\mathrm{C} 2 \mathrm{H} 5 \mathrm{OH})$, benzena $(\mathrm{C} 6 \mathrm{H} 6)$, karbondioksida $\left(\mathrm{CO}_{2}\right)$, gas belerang/sulfur-hidroksida $(\mathrm{H} 2 \mathrm{~S})$ dan asap/gas - gas lainnya di udara. Sensor ini terdiri dari 4 pin, 2 pin untuk kabel sumber tegangan VCC dan GND, 2 pin digunakan untuk mengirimkan data pengukuran dalam bentuk analog ataupun digital.

\section{Sensor MQ-7}

MQ 7 merupakan sensor gas yang digunakan dalam peralatan untuk mendeteksi gas karbon monoksida (CO) dalam kehidupan sehari-hari, industri, atau mobil. Sensor ini terdiri dari 4 pin, 2 pin untuk kabel sumber tegangan VCC dan GND, 2 pin digunakan 
untuk mengirimkan data pengukuran dalam bentuk analog ataupun digital dengan menggunakan sistem ADC.

\section{Sensor Suhu DHT11}

DHT11 adalah sensor suhu dan kelembaban yang memiliki keluaran sinyal digital yang dikalibrasi dengan sensor suhu dan kelembaban yang kompleks. Sensor ini terdiri dari 3 pin, 2 pin untuk kabel sumber tegangan VCC dan GND, untuk 1 pin digunakan untuk input ke WeMos.

\section{Perancangan Perangkat Lunak}

Gambar 3 sampai dengan Gambar 5 menunjukkan diagram alir untuk sistem server, sistem user dan sistem node client.

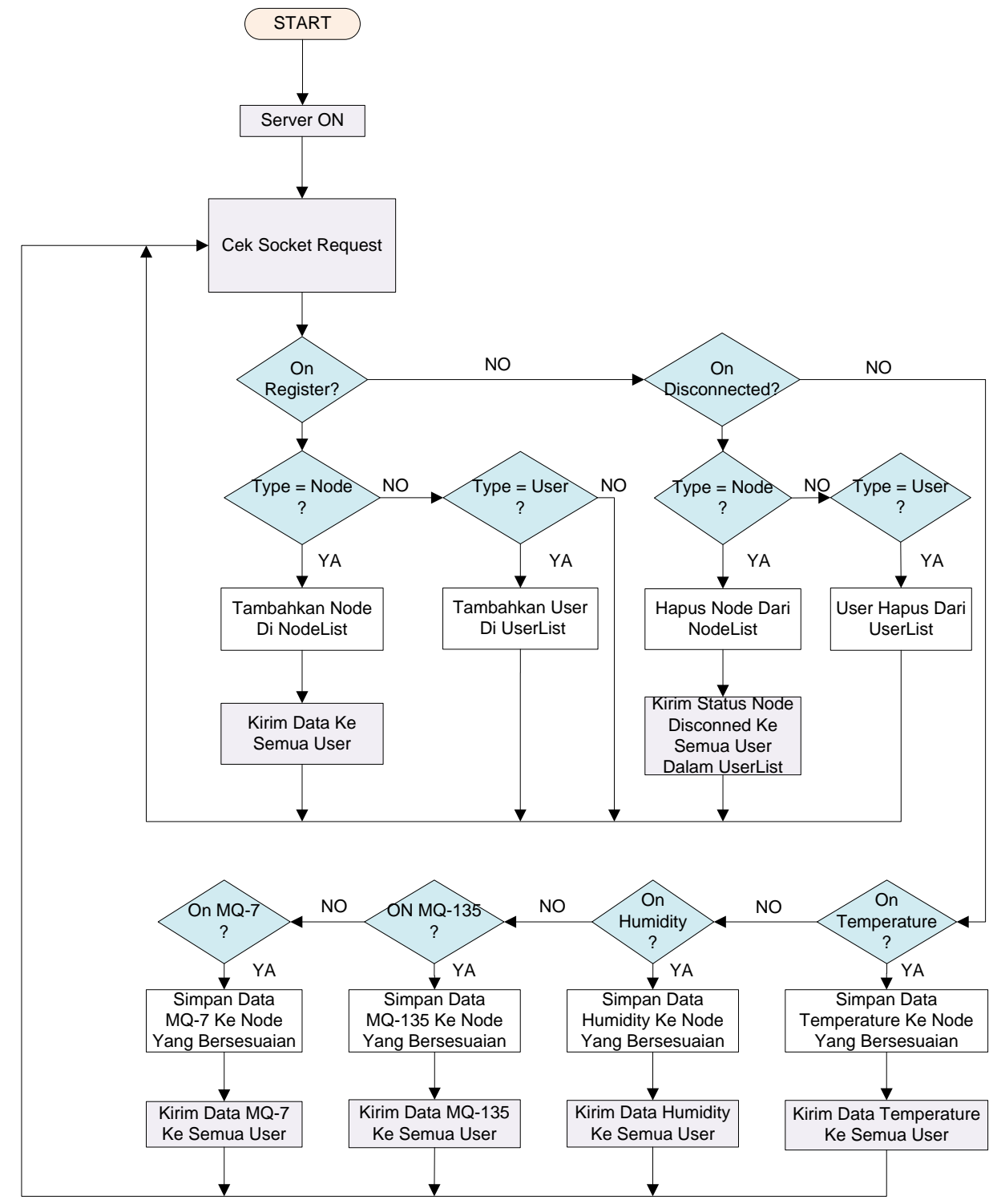

Gambar 3. Diagram alir sistem server 


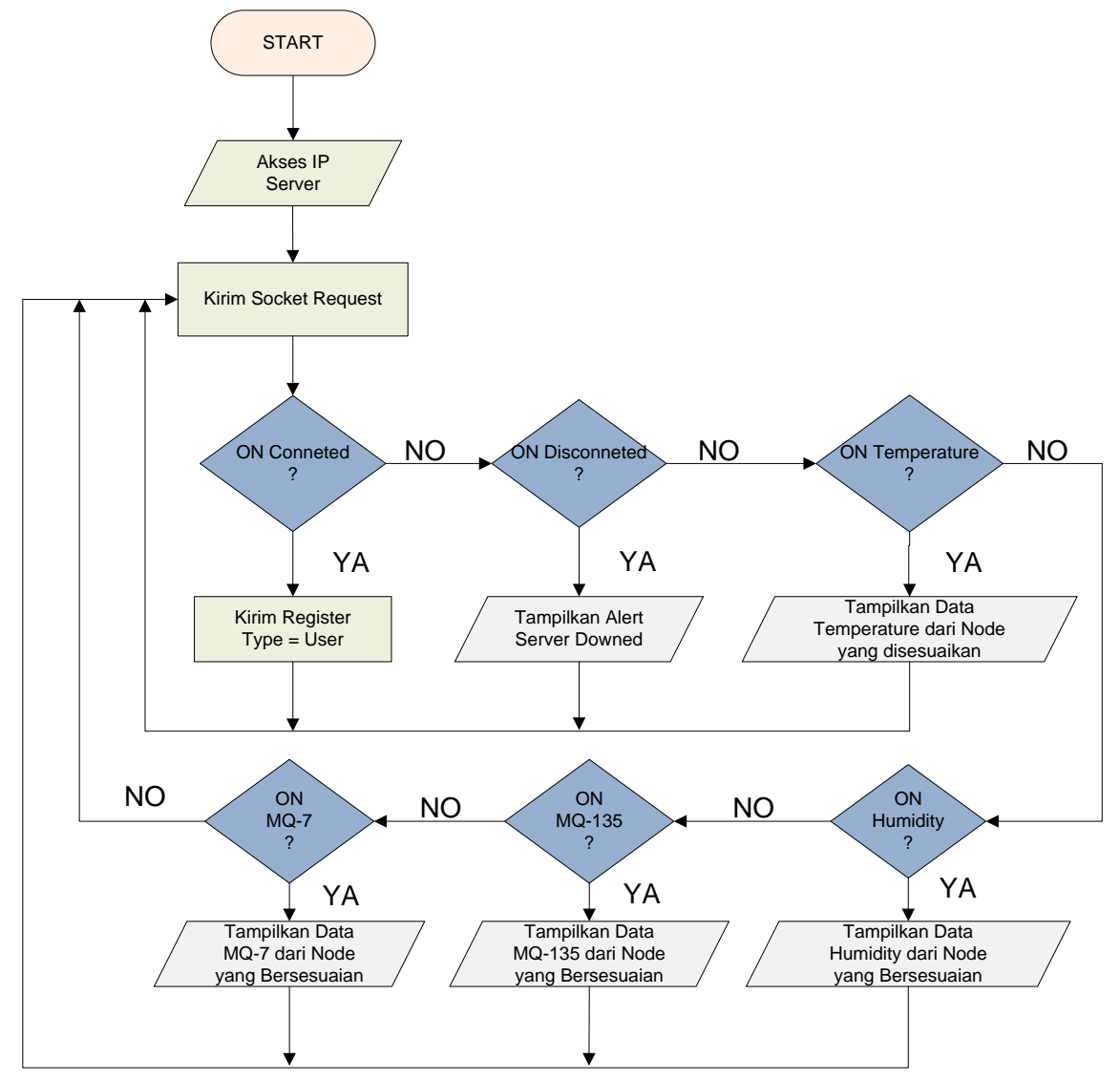

Gambar 4. Diagram alir sistem user

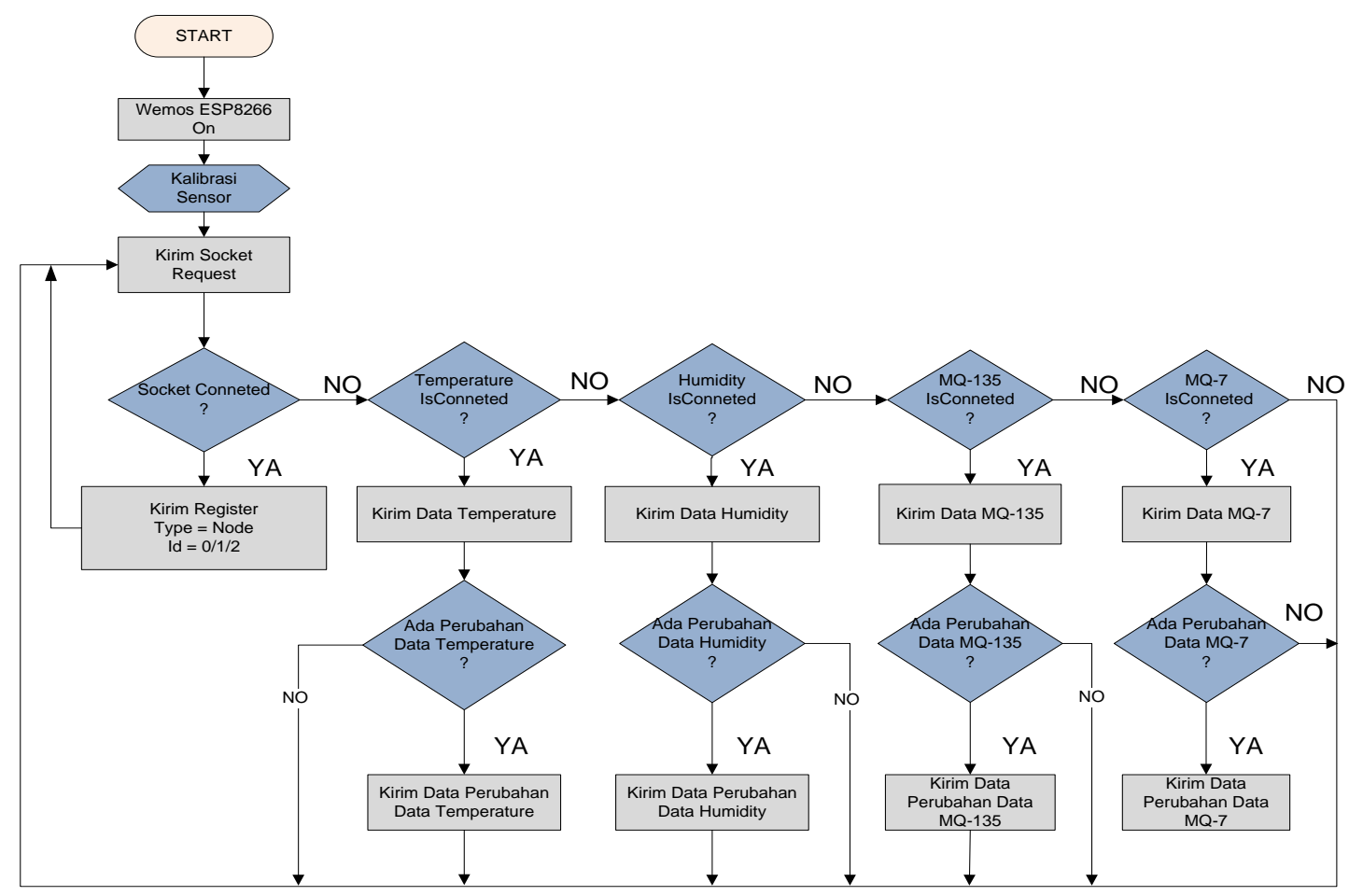

Gambar 5. Diagram alir sistem node client 


\section{Hasil dan Pembahasan}

\section{Hasil}

Gambar 6 menunjukkan skema prototipe sistem monitoring kualitas udara. Pada sistem ini terdapat 3 buah sensor yang terhubung pada mikrokontroler WeMos ESP8266 yaitu sensor MQ135, MQ7 dan DHT11. Dari 2 sensor MQ135 dan MQ7 pin analognya dihubungkan dengan IC Multiplexer pada pin IN/OUT 12, 14, dan pin IC IN/OUT 9 dan 10 dihubungkan pada pin 3, 4 digital WeMos ESP8266 sebagai saklar digital. Kemudian Pin 13 IN/OUT IC dihubungkan pada Pin Analog WeMos sebagai Command dan untuk Pin OUT sensor DHT11 dihubungkan langsung pada Pin digital WeMos ESP8266.

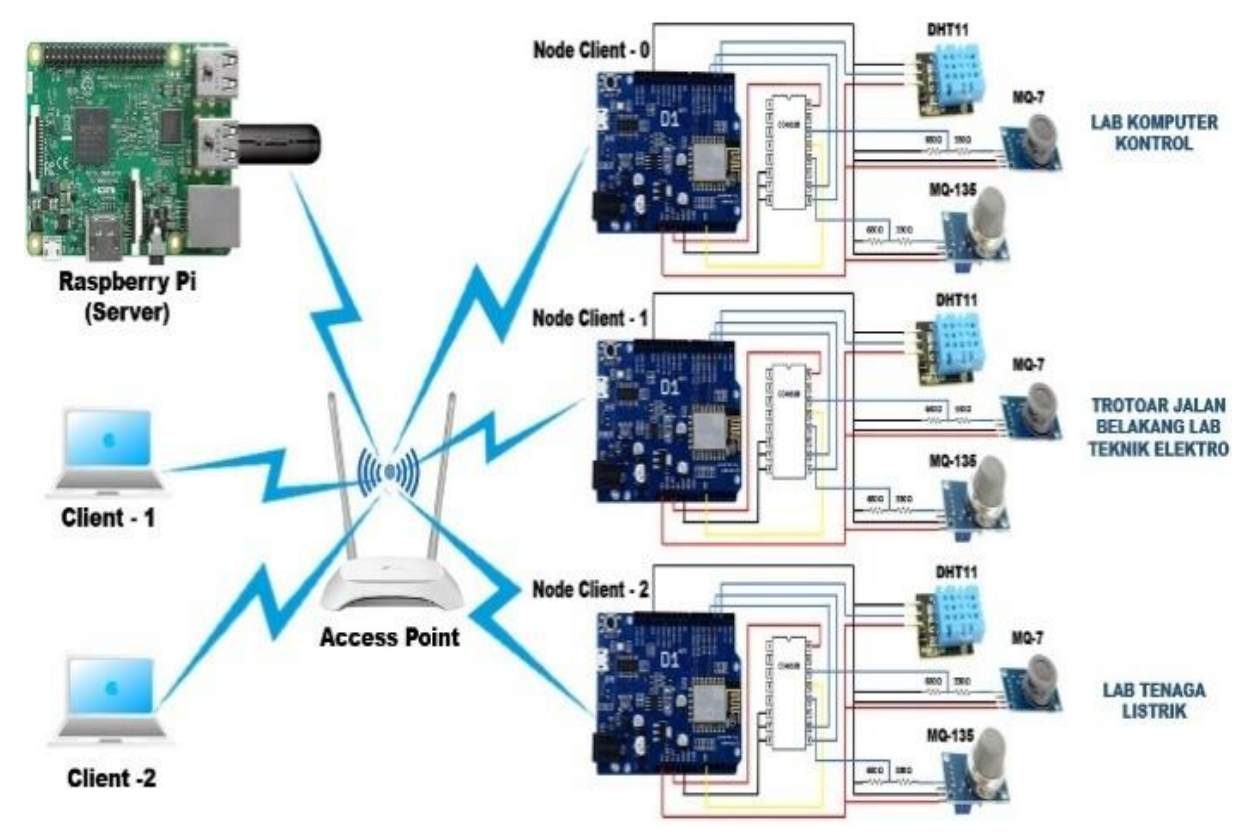

Gambar 6. Skema prototipe sistem monitoring udara

Setelah dilakukan pengujian dari komponen pada masing-masing alat, selanjutnya dilakukan pengujian sistem secara keseluruhan. Proses dimulainya sistem monitoring ini, yaitu server (Raspberry Pi) dan ketiga nodeclient (WeMos Esp8266) dikoneksikan pada jaringan yang sama yaitu pada AccessPoint dengan menggunakan jarigan Wifi Local. Setelah server dikoneksikan dan dijalankan dengan membuka terminal dan menuliskan perintah "Node Server.js". Selanjutnya jika ketiga nodeclient sudah terhubung dengan server maka data dari pengukuran sensor DHT11, MQ135 dan MQ7 otomatis dikirim ke server secara terus menerus. Setelah client terkoneksi dengan Server (Clients- Connected), maka respon dari server tersebut adalah memberikan halaman index, style, script dan Socket.io yang berfungsi untuk membuat pertukaran data secara real time pada platform tertentu. Contoh tampilan halaman web monitor kualitas udara seperti pada Gambar 7. 


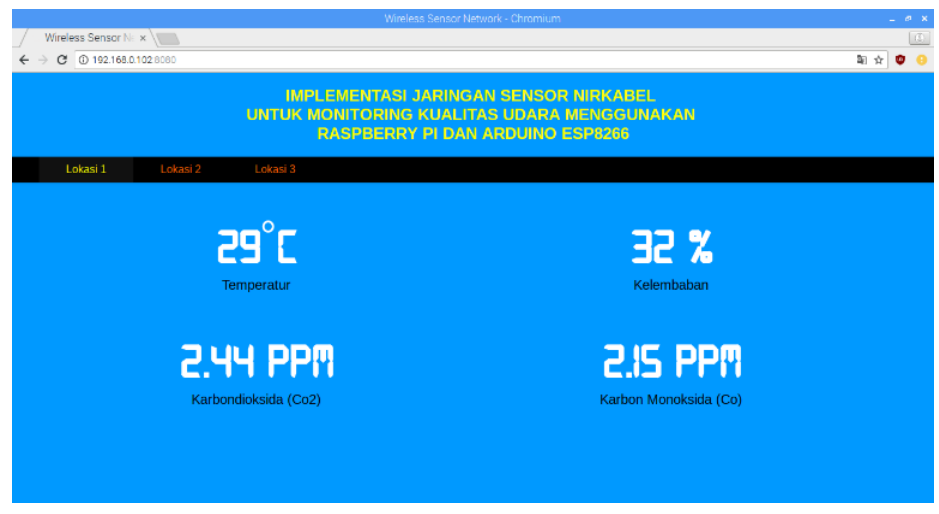

Gambar 7. Tampilan web monitoring kualitas udara

\section{Pembahasan}

Percobaan hasil pengukuran kualitas udara dilakukan di tiga titik lokasi yang berbeda. Percobaan pengukuran pada lokasi pertama untuk Node Client-0 diletakan didalam ruangan Laboratorium Komputer Kontrol (dalam ruangan, tanpa AC). Pada lokasi kedua, Node Client-1 diletakkan di trotoar jalan belakang Laboratorium Teknik Elektro (luar ruangan, dekat jalan). Pada lokasi ketiga, Node Client-2 diletakan di Laboratorium Tenaga Listrik (dalam ruangan, ber-AC). Hasil pengukuran ketiga lokasi tersebut dapat dilihat pada Tabel 1.

Tabel 1 Hasil Pengukuran Kualitas Udara di Tiga Lokasi

\begin{tabular}{llcccc}
\hline No. & Lokasi & $\begin{array}{c}\text { Suhu } \\
\left({ }^{\circ} \mathrm{C}\right)\end{array}$ & $\begin{array}{c}\text { Kelembaban } \\
(\%)\end{array}$ & $\begin{array}{c}\text { Kadar } \mathrm{CO}_{2} \\
(\mathrm{ppm})\end{array}$ & $\begin{array}{c}\text { Kadar CO } \\
(\mathrm{ppm})\end{array}$ \\
\hline 1 & Dalam Ruangan tanpa AC & 29 & 32 & 2,44 & 2,15 \\
2 & Luar ruangan, dekat jalan & 32 & 67 & 193,62 & 4,86 \\
3 & Dalam Ruangan ber-AC & 27 & 63 & 7,5 & 0,87 \\
\hline
\end{tabular}

Berdasarkan pengukuran di tiga lokasi berbeda diperoleh bahwa suhu paling rendah pada lokasi ketiga, hal ini dikarenakan ruangan tersebut berpendingin udara. Kadar gas karbonmonoksida $(\mathrm{CO})$ dan gas karbondioksida $\left(\mathrm{CO}_{2}\right)$ paling tinggi pada lokasi kedua, karena lokasi ini berada di luar ruangan dekat dengan jalan. Sedangkan kadar kedua gas tersebut paling rendah pada lokasi ketiga karena lokasi ini adalah ruang tertutup sehingga relatif bebas dari gas buang kendaraan bermotor. Begitu juga pada lokasi kedua yang merupakan lokasi dalam ruangan tetapi menggunakan jendela sebagai sirkulasi udara, kadar gas karbonmonoksida dan gas karbondioksida relatif rendah. 


\section{Kesimpulan}

Penelitian ini telah berhasil menerapkan teknologi JSN untuk membangun prototipe sistem monitor kualitas udara berbasis web dengan menggunakan Raspberry Pi sebagai server dan modul Wemos D1 sebagai modul wifi. Sistem telah bekerja dengan baik sesuai dengan yang diharapkan. Hasil data pengukuran sensor dari 3 Node Client dapat dikirim ke server dan diteruskan ke client yang terkoneksi melalui komunikasi protokol Websocket dan ditampilkan dalam web browser secara real time. Sistem telah diuji untuk mengukur kualitas udara di tiga lokasi berbeda. Pada uji coba yang dilakukan pada lokasi pertama Laboratorium Komputer Kontrol (dalam ruangan, tanpa $\mathrm{AC}$ ) diperoleh pembacaan suhu $2^{\circ} \mathrm{C}$, kelembaban $32 \%$, kadar gas $\mathrm{CO}_{2}$ dan $\mathrm{CO}$ bertutur-turut 2,44 ppm dan 2,15 ppm. Lokasi kedua di trotoar jalan (luar ruangan, dekat jalan) diperoleh data $32^{\circ} \mathrm{C}, 67 \%$, 193,62 ppm, 4,86 ppm, sedangkan pada lokasi ketiga di Laboratorium Tenaga Listrik (dalam ruangan, ber-AC) diperoleh data $27^{\circ} \mathrm{C}, 63 \%, 7,5$ ppm dan 0,87 ppm. Hasil pengukuran ketiga lokasi diperoleh data bahwa di trotoar jalan gas Karbondioksida $\left(\mathrm{CO}_{2}\right)$ dan karbon monoksida (CO) dengan kadar tertinggi yaitu mencapai berturut-turut 140.85 PPM dan 7.02 PPM.

\section{Daftar Pustaka}

Af'idah, D. I., Rochim, A. F., \& Widianto, E. D. (2014). Perancangan jaringan sensor nirkabel (JSN) untuk memantau suhu dan kelembaban menggunakan nRF24L01+. Jurnal Teknologi dan Sistem Komputer, 2(4), 267-276.

Ardiyanto, L., \& Sumiharto, R. (2012). Implementasi jaringan sensor nirkabel berbasis Xbee studi kasus pemantauan suhu dan kelembaban. IJEIS,October 20(2), 119-130. https://doi.org/http://dx.doi.org/10.22146/ijeis.2422

D-robotics UK. (2010). Temperature sensor DHT 11 humidity \& temperature sensor. $D$ Robotics, 1-9. Retrieved Juni 7, 2018 from http://www.micropik.com/PDF/dht11.pdf\%0Awww.droboticsonline.com

ESP8266 Datasheet. (2015). ESP8266EX datasheet. Espressif Systems Datasheet, 131. Retrieved September 9, 2018 from https://www.adafruit.com/images/product-files/2471/0AESP8266 Datasheet EN v4.3.pdf

Ilham, J., Ridwan, W., Harun, E.H. (2018). Rancang bangun gas meter berbasis mikrokontroler arduino nano dengan sensor MQ-2 sebagai pengembangan Reaktor gas tipe fixed dome multi input skala laboratorium. Prosiding Seminar Nasional Teknik Elektro FORTEI 2018, 159-162.

Panser, M. B., Yahya Widhi, B. A. (2018). Analisis perbandingan kinerja protokol websocket dengan protokol SSE pada teknologi push notification. Jurnal 
Pengembangan Teknologi Informasi Dan IImu Komputer, 2(6), 2235-2242.

Pi, R. (2016). Datasheet Raspberry Pi Compute Module (CM1) Raspberry Pi Compute Module 3 (CM3) Raspberry Pi Compute Module 3 Lite (CM3L), 3 (October), $0-$ 21. Retrieved September 12, 2018 from https://www.raspberrypi.org/documentation/hardware/computemodule/RPICM-DATASHEET-1 0. pdf\%0Ahttps://www.sparkfun.com/products/13825

Widodo, S., Amin, M. M., Sutrisman, A., \& Putra, A. A. (2017). Rancang bangun alat monitoring kadar udara bersih dan gas berbahaya $\mathrm{CO}, \mathrm{CO} 2$, dan $\mathrm{CH} 4$ di dalam ruangan berbasis mikrokontroler. Jurnal Pseudocode 4 (2), 105-119.

Rachman, F. Z. (2016). Implementasi jaringan sensor nirkabel menggunakan Zigbee pada monitoring tabung inkubator bayi. JNTE, 5(2), 207-216.

Rachman, F. Z. (2017). Implementasi jaringan sensor nirkabel Zigbee menggunakan topologi Mesh pada pemantauan dan kendali perangkat ruang, 4(2), 201-206.

Richardson, M., \& Wallace, S. (2012). Guetting Started with Raspberry Pi.

Ridwan, W., Nasibu, I.Z., Dako, R. D. R., Wiranto, I. (2017). Sistem pemantauan dan pengendalian penerangan rumah berbasis web menggunakan Raspberry $\mathrm{Pi}$. Prosiding Seminar Nasional Teknik Elektro (Senter) 2017, 225-231.

Ridwan, W., Haryanto, D. H., Nasibu, I. Z. (2020). Rancang bangun model pengendali katup cerdas bak penampungan air PDAM. Jurnal Teknik Media Pengembangan IImu dan Aplikasi Teknik, 19(1).

Susana, R., Darlis, A. R., \& Aqli, S. (2016). Implementasi wireless sensor network prototype sebagai fire detector menggunakan Arduino Uno. Jurnal Elektro Dan Telekomunikasi Terapan, 2(1), 53-60. https://doi.org/10.25124/jett.v2i1.93

Usman, F. R., Ridwan, W., Nasibu, I. Z. (2019). Sistem peringatan dini bencana banjir berbasis mikrokontroler Arduino. Jambura Journal of Electrical and Electronics Engineering, 1(1), 1-6.

UURI No. 23. (1997). Undang Undang No . 23 Tahun 1997 Tentang : Pengelolaan lingkungan hidup

Yuliza, H. P. (2016). Rancang bangun kompor listrik digital IOT. Jurnal Teknologi Elektro, 7(3), 187-192. 